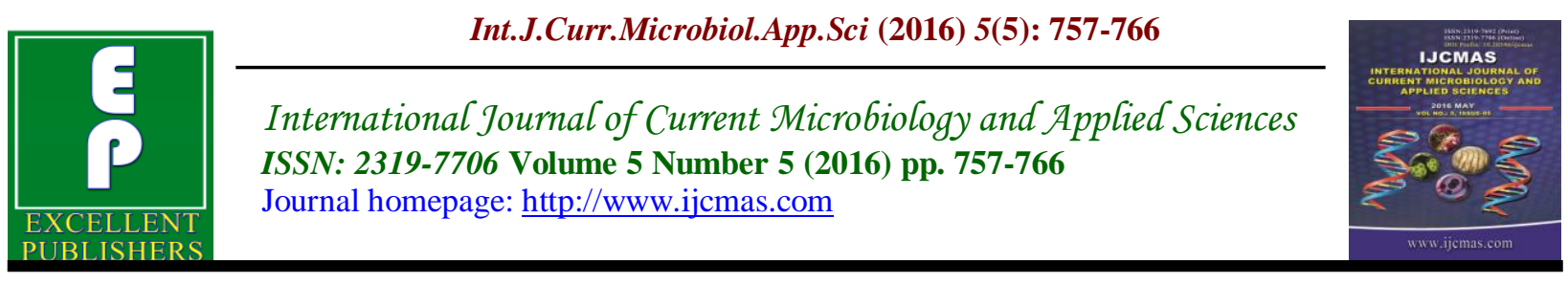

Original Research Article

http://dx.doi.org/10.20546/ijcmas.2016.505.077

\title{
Detection of Local Isolates of Canine Distemper Virus by Reverse- Transcription Polymerase Chain Reaction
}

\author{
Swati $^{{ }^{*}}$, Dipak Deka ${ }^{2}$ and Ramneek ${ }^{2}$ \\ ${ }^{1}$ CSIR-Institute of Genomics \& Integrative Biology, New Delhi-110020, India \\ ${ }^{2}$ School of Animal Biotechnology, GADVASU, Ludhiana-141004, India \\ *Corresponding author
}

\begin{abstract}
A B S T R A C T
Keywords

Canine distemper virus, RT-PCR, isolation, viral passages, molecular characterization.

\section{Article Info}

Accepted:

20 April 2016

Available Online:

10 May 2016

Distemper is a disease of several canids caused by canine distemper virus (CDV). The present study aimed to detect CDV directly from the swab samples of the suspected dogs by diagnostic RT-PCR. The positive samples were then subjected to virus isolation in MDCK cells after growing it in mitogen stimulated dog lymphocytes and the presence of the viral RNA again was confirmed by RT-PCR. Further, haemagglutinin $(\mathrm{H})$ and largeprotein $(\mathrm{L})$ genes were amplified and cloned into pGEMT Easy cloning vector, sequenced and phylogenetically characterized with the available reference CDV strains in GeneBank. Three samples were detected CDV positive by RT-PCR from a total of 50 samples and virus could be successfully isolated from one sample in MDCK cells after lymphocyte culture. After a number of serial passages, there were no consistent CPE observed but viral RNA could be detected from all the cell culture harvests of all passages which confirmed the presence of CDV. Mitogen stimulated dog lymphocyte culture proved to be an effective and economical method to isolate wild-type CDV from clinical samples. Partial haemagglutinin $(\mathrm{H})$ and large protein $(\mathrm{L})$ gene sequences of one of the CDV isolates made a distinct clade in phylogenetic tree which was clearly separated from commercial CDV vaccine groups (Lederle, Ondersteport, Convac and Synder Hill).
\end{abstract}

\section{Introduction}

Canine distemper virus (CDV) a Morbillivirus under Paramyxoviridae family is a contagious pathogen that causes canine distemper in carnivores. The disease is characterized with generalized infection with respiratory, nervous and gastrointestinal signs (Scagliarini et al., 2003). CDV infects a broad range of animals such as domestic dogs, foxes, wolves, ferrets, minks and recently it has been reported to infect seals, lions and tigers (Guo et al., 2013). CDV is a single-stranded, RNA virus with genome size of $15.7 \mathrm{~Kb}$ which consists of genes for one nonstructural protein (C) and six structural proteins: large protein $(\mathrm{L})$, haemagglutinin (H), phosphoprotein (P), nucleocapsid protein $(\mathrm{N})$, fusion protein $(\mathrm{F})$ and matrix protein $(\mathrm{M})$.

Initially, CDV isolation has been tried by different techniques and in different cells. 
The attenuated form of CDV can readily be grown in epithelial and fibroblast cell lines but isolation of virulent $\mathrm{CDV}$ in these cells is difficult (Appel, 1978). CDV has been cultivated in canine alveolar macrophages (Appel and Jones, 1967); chorioallantoic membrane of embryonated chicken eggs (Ezeibe 2005; Haig 1956); co-cultivation of infected tissues with mitogen stimulated lymphocytes derived from healthy dogs (Appel et al., 1992). But all of these methods are time consuming and multiple blind passages are needed before any proper cytopathic effects (CPE) of the virus become visible. CDV has been successfully isolated in cells like MDCK (canine epithelial kidney cells), MV1 LU (mink lung), Vero (African green monkey kidney cells) (Lednicky et al., 2004), B95a (cells from marmosets) (Kai et al., 1993), HmLu and BHK (hamster cell lines) (Sultan et al., 2009). It is reported that CDV isolation in Vero cells expressing dSLAM receptor (dog-signalling lymphocyte activation molecule) is easy and simplest as CPE were observed from first day post infection (Seki et al., 2003).

Although live attenuated vaccines have been widely used in most of the countries for controlling the disease yet $\mathrm{CD}$ has been reported in some vaccinated animals (Tatsuo et al., 2001). It has been reported that genomic differences occur between the wild-type CDV and the vaccine strains ( $\mathrm{Li}$ et al., 2014). $\mathrm{H}$ gene is considered to be highly mutagenic (Martella et al., 2006). The phylogenetic work performed based on $\mathrm{H}$ gene, showed six major genetic lineages i.e. America-1 (most vaccine strains), America2, Europe, Artic-like, Asia-1, Asia-2 (Zhao et al., 2010) of CDV from different geographical areas.

In India, limited reports are available on isolation of CDV from clinical samples. Pawar et al (Pawar et al., 2011) isolated
CDV from B95a cells which is a marmoset B lymphoblastoid cells and performed sequence analysis of partial $\mathrm{N}$ gene. Virus isolation is not only important for diagnosis purpose but also to provide further information about the genotype and origin of the virus based on direct sequence analysis of their genes. Therefore, this study aimed to isolate CDV from clinical samples collected from CDV suspected dogs, detect it by RTPCR and further characterize it by cloning, sequencing and phylogenetic analysis of partial $\mathrm{H}$ and $\mathrm{L}$ gene sequences.

\section{Materials and Methods}

\section{Clinical Samples}

Ocular and nasal swabs were collected in sterile PBS from a total of 50 CD suspected dogs brought to Small Animal Veterinary Clinics, GADVASU, Ludhiana. The swabs were squeezed properly in PBS, centrifuged at $5000 \mathrm{rpm}$ for 5 minutes and the supernatant was collected into a new sterile tube. Blood sample (2-4ml) was also taken aseptically in EDTA vial from cephalic vein of a healthy dog for lymphocyte isolation. The work has been approved by the Institutional Animal Ethical Committee (IAEC).

\section{Detection of CDV in the Clinical Samples}

Total RNA was isolated directly from suspected swab samples along with one CDV vaccine strain (Novibac-DHPPi) as positive control. $500 \mathrm{ml}$ of the supernatant of the ocular and nasal discharge were used to isolate RNA using $1 \mathrm{ml}$ of Trizol reagent (Ambion, Life Technologies) as recommended. RNA quality and quantity were determined by spectrophotometric analysis with a Nanodrop 1000 (Thermo Scientific, USA) and then stored at $-80^{\circ} \mathrm{C}$ for further use. RNA templates having 
absorbance ratio (260/280) between 1.9 and 2.0 were subjected to cDNA synthesis using First strand cDNA synthesis Kit (Thermo Scientific, USA) with random hexamer primer, as per the manufacturer's instruction.

CDV presence was confirmed by newly designed Large protein (L) gene based diagnostic primers. The sequences of the forward and reverse primers were 5'CTGCAATCAACTGGGGCTTT-3' and 5'GAAGGTCTAGGTAAATCATGTAACAG T-3' respectively. The PCR mixture was prepared in a final volume of $25 \mathrm{ml}$ containing $10 \mathrm{ml}$ cDNA template, $0.4 \square \mathrm{M}$ each of forward primer and reverse primer, 1X of PCR reaction buffer with $15 \mathrm{mM}$ of $\mathrm{MgCl} 2,2 \mathrm{mM}$ each dNTPs mix and 2 unit Taq DNA-Polymerase (Invitrogen). The reaction was carried out in Thermal Cycler (Veriti, Applied Biosystems) with the following conditions: initial denaturation at $94^{\circ} \mathrm{C}$ for 3 minutes, 35 cycles of denaturation at $94^{\circ} \mathrm{C}$ for 30 seconds, annealing at $55^{\circ} \mathrm{C}$ for 30 seconds and extension at $72^{\circ} \mathrm{C}$ for 30 seconds followed by a final extension at $72^{\circ} \mathrm{C}$ for 7 minutes. The PCR product was then subjected to agarose gel (2\%) electrophoresis and then photographed.

\section{Cell Culture and Media}

Dog lymphocytes were isolated by density gradient method using HiSep1077 (HiMedia) as described by Boyum (Boyum, 1968). The cells were cultured in RPMI1640 medium (Sigma-Aldrich) supplemented with $10 \%$ serum in $25 \mathrm{~cm} 2$ flask and kept at $37^{\circ} \mathrm{C}$ in a $\mathrm{CO} 2$ incubator. The lymphocytes were stimulated by mitogen (PHA) phytohaemagglutinin A (Sigma) at a concentration of $15 \mu \mathrm{g} / \mathrm{ml}$ for 48 hrs before inoculation with the CDV suspected samples. Madin Darby Canine
Kidney (MDCK) cell line was used for isolation of the virus. The cells were cultured routinely in polystyrene tissue culture $25 \mathrm{~cm} 2$ flask at $37^{\circ} \mathrm{C}$ in a $5 \%$ humidified $\mathrm{CO}_{2}$ atmosphere in DMEM (Dulbecco's Minimum Essential Medium). The growth media was supplemented with $10 \%$ heat-inactivated fetal bovine serum (Gibco) and 1X antibiotic- antimycotic solution (HiMedia).

\section{Virus Isolation}

RT-PCR positive ocular swab sample was subjected to virus isolation in primary lymphocytes and MDCK cells. The swab sample was vortexed, 2-3 drops of antibiotic (Antibiotic-Antimycotic Solution 100X Liquid Endotoxin Tested, HIMEDIA) was added and then incubated at $37^{\circ} \mathrm{C}$ for $1 \mathrm{hrs}$. The sample was then centrifuged at 8000 rpm for 10 minutes and the supernatant was collected into a new sterile tube which was used fresh or stored at $-80^{\circ} \mathrm{C}$ till further use. $500 \mu \mathrm{l}$ of the inoculum was inoculated into a $25 \mathrm{~cm} 2$ tissue culture flask containing dog lymphocytes which was stimulated by mitogen PHA for $48 \mathrm{hrs}$. The flask was incubated at $37^{\circ} \mathrm{C}$ for 5-6 days in $\mathrm{CO} 2$ incubator. Further, the cells were harvested and after three round of freezing and thawing, the content of the flask was centrifuged at $1500 \mathrm{rpm}$ for 10 minutes in a $15 \mathrm{ml}$ centrifuge tube and the supernatant was collected which served as the inoculum to infect a sub-confluent monolayer of MDCK cells in serum free DMEM media (maintenance media). The flask was incubated at $37^{\circ} \mathrm{C}$ for 1 hour for virus adsorption following inoculation with $500 \mu \mathrm{l}$ of the virus inoculum and then maintenancemedia having $2 \%$ serum was added to make the volume $5 \mathrm{ml}$. An uninoculated flask of MDCK cells was used as negative control. The flasks were incubated at $37^{\circ} \mathrm{C}$ in $\mathrm{CO} 2$ incubator and examined daily for cytopathic 
effects (CPE). Irrespective of the CPE observed, the samples were subjected to eight serial passages and the presence of CDV was confirmed by RT-PCR using the same set of diagnostic primers.

\section{Cloning and Sequencing of CDV Partial $H$ and $L$ Gene}

PCR was carried out for the bulk amplification of partial $\mathrm{H}$ and $\mathrm{L}$ genes using cDNA prepared from one positive sample. The forward and reverse primers used for $\mathrm{H}$ gene amplification were 5'AACTTAGGGCTCAGGTAGTCCA-3' and 5' - CAATGCAGGCACCATCCAGGT-3' respectively, whereas the detail of primers used for L gene has already been mentioned. The bulk amplified PCR products were subjected to agarose gel (1\%) electrophoresis and then purified by using GeneJET PCR Gel extraction Kit (Thermo Scientific, USA). The purified product was ligated into pGEMT Easy cloning vector (Promega, USA), transformed into Top10 competent cells and spread on agar plate containing Ampicillin $(100 \mathrm{mg} / \mathrm{ml})$, X-gal $(20 \mu \mathrm{g} / \mathrm{ml})$ and IPTG $(100 \mathrm{mM})$. Recombinant white colonies were picked, grown overnight in LB broth at $37^{\circ} \mathrm{C}$ on a shaker incubator and subjected to plasmid isolation by alkaline lysis method as per the protocol of Sambrook and Russel (Sambrook and Russell, 2001). The recombinant plasmids carrying CDV genes were confirmed by EcoRI, restriction endonuclease digestion which released specific gene inserts. The positive recombinant plasmids were sequenced by commercial outsourcing.

\section{Sequence Analysis of Partial $H$ and $L$ Gene}

The obtained nucleotide sequences of CDV $\mathrm{H}$ and $\mathrm{L}$ genes were subjected to BLASTn (Altschul et al., 1990) analysis for comparing sequence identities and variations with other sequences of $22 \mathrm{CDV}$ strains around the world present in NCBI database along with the CDV vaccine strains. Amino acid sequences were further subjected to multiple sequence alignment using ClustalW method (Thompson et al., 1990; Sievers et al., 2011). The partial amino acid sequences of the genes along with the other CDV strains from different geographical areas were used to construct the phylogenetic tree using maximum likelihood (ML) method in MEGA 6.06 software (Tamura et al., 2013). The topological accuracy of the tree was estimated by 1000 bootstrap replicates.

\section{Results and Discussion}

There are very limited reports on CDV isolation from the clinical samples from India and it is a well established fact that isolation of wild-type CDV is tedious and difficult. Out of 50 suspected samples, CDV could be detected in only three samples by RT-PCR as an amplicon of 268 bp were observed (Fig. 1). Details of the positive samples obtained are mentioned in Table 1.

One of the RT-PCR positive ocular swab samples was subjected to CDV isolation in MDCK cells after growing the virus in mitogen stimulated dog lymphocytes. When the inoculum from the CDV infected lymphocyte flask was used to infect monolayer of MDCK cells, no consistent $\mathrm{CPE}$ in initial passages. However rounding, clumping and aggregation of the cells was visible in 3rd-4th passage onward. Existence of small syncytia in MDCK cells was also observed in the seventh passage (Fig. 3). In addition to the observed CPE, presence of CDV was confirmed by successful amplification of $\sim 268$ bp product by diagnostic RT-PCR from RNA extracted from cell culture harvests of all passages 
(Fig. 4). Similarly, Tan et al (Tan et al., 2011) isolated a virulent strain of CDV (ZJ7 isolate) in MDCK cell, which showed cytopathogenic effects like syncytia after six passages of the virus. Lednicky et al (Lednicky et al., 2004) isolated wild-type CDV in different cells like MDCK, MV1 $\mathrm{Lu}$, Vero cells and reported that CDV isolation was most effective in MDCK cells, though CPE were most evident in Vero cells. Appel et al (Appel et al., 1992) reported that unstimulated lymphocytes also support CDV growth, but to a lesser degree whereas optimal CDV growth was found in PHA (phytohemagglutinin) and (PWM) pokeweed mitogen stimulated peripheral blood lymphocytes.

Table.1 Description of CDV Positive Cases

\begin{tabular}{|c|c|c|c|c|c|c|}
\hline Sl. No & Case No. & Sample type & Sex & Breed & Age & Place \\
\hline 1 & 2888 & Ocular, Nasal swabs & Female & Stray dog & $1.5 y r s$ & Ludhiana \\
\hline 2 & 12411 & Ocular, Nasal swabs & Male & Labrador & 8 yrs & Ludhiana \\
\hline 3 & 13529 & Ocular, Nasal swabs & Female & German shepherd & 4yrs & Sangrur \\
\hline
\end{tabular}

Fig.1 PCR Amplification of 268bp Fragment of the L Gene of Cdv by Diagnostic Primer of Three Positive Samples: Lane 1: 2888 (Ocular), Lane 2: 2888 (Nasal), Lane 3: 12411 (Ocular), Lane 4: 12411 (Nasal), Lane 5: 13529 (Ocular), Lane 6: 13529 (Nasal), Lane 7:

1kb Plus Dna Ladder (Fermentas), Lane 8: Nobivac-Dhppi Vaccine, Lane 9: Ntc

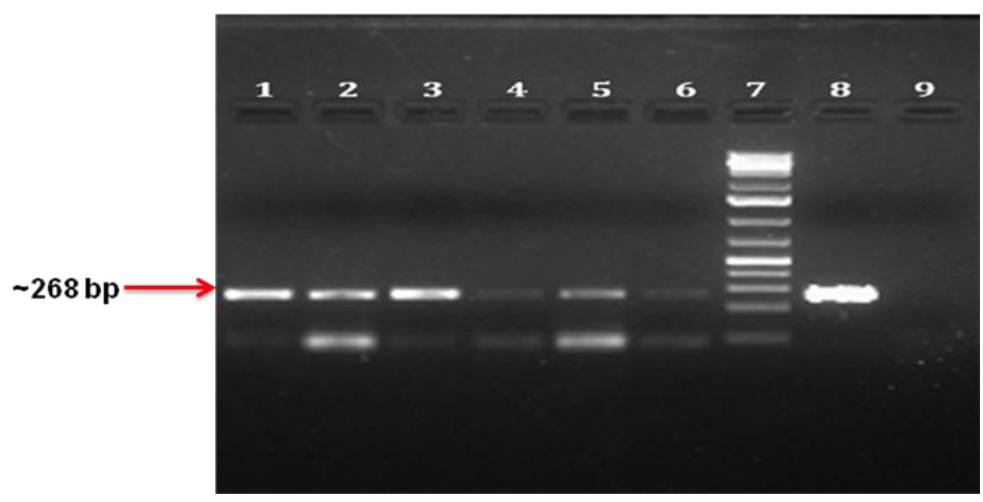

Fig.2 CPE of the Virus (a) cdv Infected Dog Lymphocytes (b) non infected mdck cells(c) cdv infected mdck cells (passage-7). Magnificaion 10x.
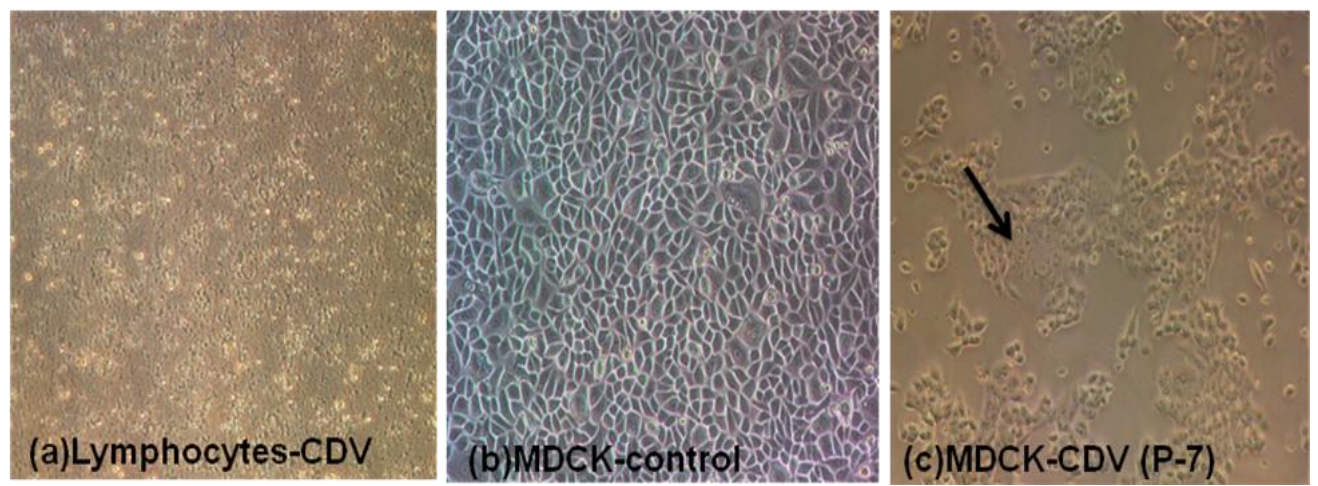
Fig.3 PCR Amplification of Different Viral Passages by Diagnostic Primer: Lane 1-8: Passage 1-8, Lane 9: Nobivac-Dhppi Vaccine, Lane 10: Ntc, Lane 11: 1kb Plus Dna Ladder (Fermentas)

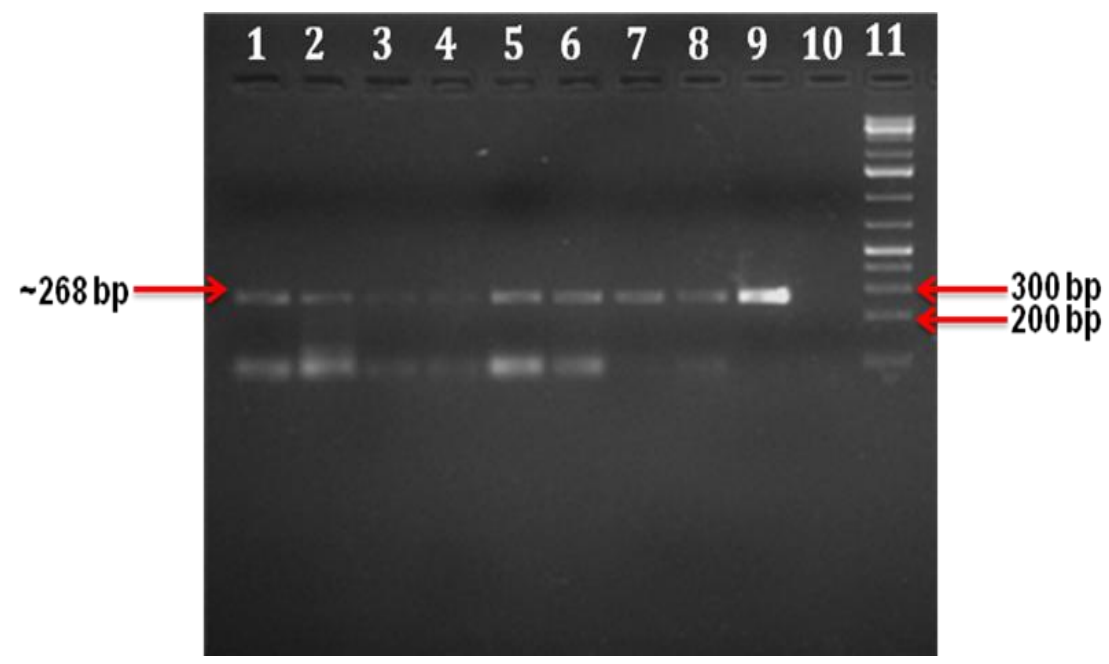

Fig.4 RE Digestion of Cdv Genes by Ecori Enzyme: Lane M: 1 Kb Plus Dna Ladder (Fermentas), Lane H: Insert Release Of 1169bp Size Of H Gene, Lane L: Insert Release of 268bp Size of L Gene

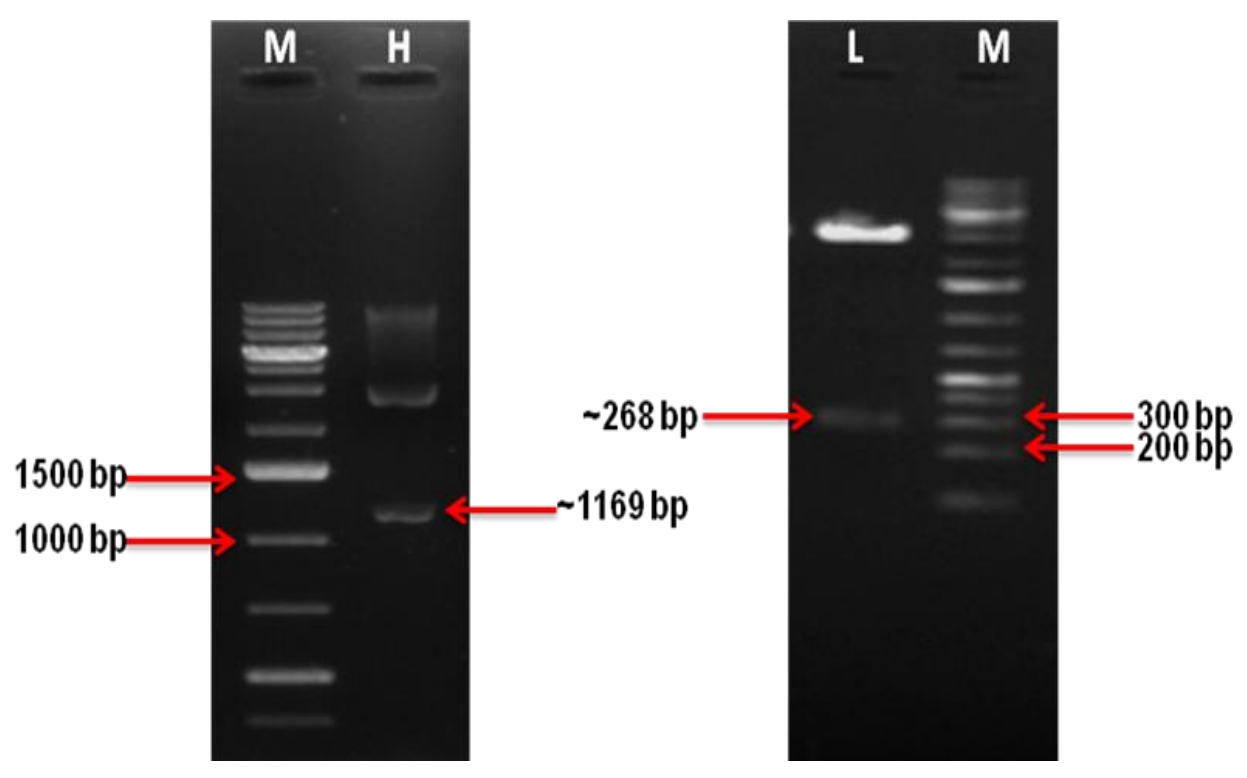


Fig.5 Phylogenetic tree of CDV strains, on the basis of the amino acid alignment (a) partial H protein (b) partial L protein of India LDH strain, constructed using maximum likelihood method. The scale bar indicates the branch length equivalent to 0.02 amino acid substitutions per site; the numbers on branches are percentages of bootstrap values determined for 1000 iterations.

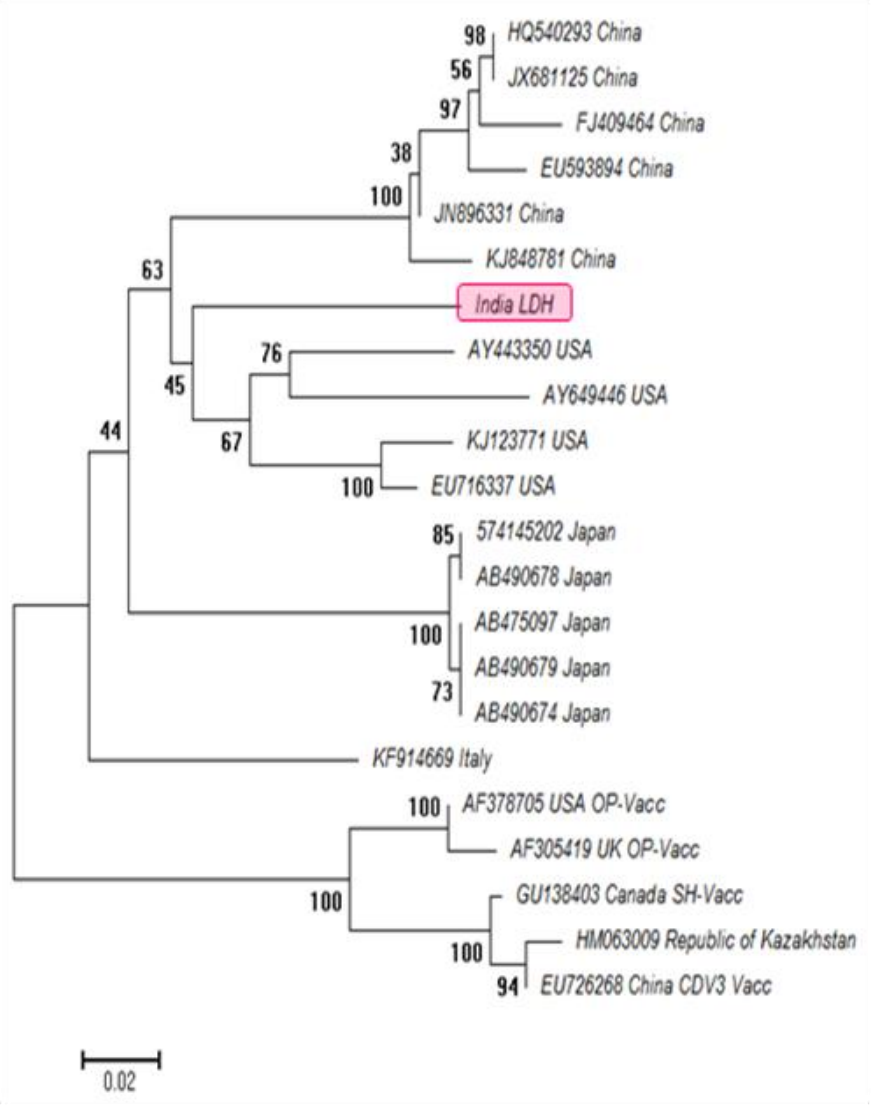

(a)

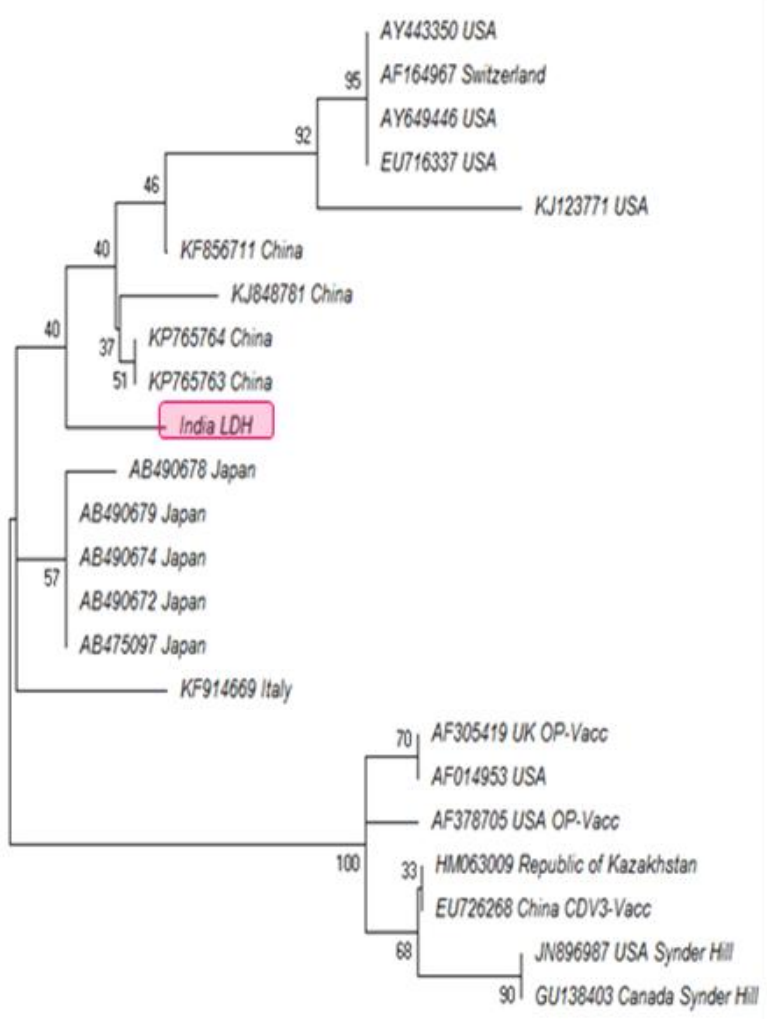

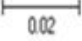

(b)
CDV have been successfully isolated in a number of different cells earlier. Vero cells expressing dog SLAM receptor is not only useful for CDV isolation but also passaging the virus without any alteration of its genome (Lan et al., 2006). B95a cells which intrinsically expresses mammalian SLAM receptor is also considered good for CDV isolation. But due to unavailability of such cells in many laboratories, lymphocytes from healthy dogs would be a simple option for the multiplication and isolation of virulent CDV from clinical samples. Stimulated dog lymphocytes or any canine lymphoid cell-line can be an easy option to isolate and propagate virulent $\mathrm{CDV}$ as SLAM receptor is expressed on cells of the immune system. Therefore, stimulated dog lymphocyte method as described in the present study for growing, multiplying and further isolating virulent CDV from clinical samples is both useful and economical for many laboratories.

The PCR amplified CDV partial $\mathrm{H}$ and $\mathrm{L}$ genes of local isolate in this study were successfully cloned into pGEMT Easy vector and the recombinant plasmids prepared from the selected clones when screened for the presence of desired inserts 
released an 1169 bp and 268 bp $\mathrm{H}$ and L genes specific products by EcoRI restriction endonuclease digestion respectively (Fig. 5). The plasmids carrying $\mathrm{CDV} \mathrm{H}$ and $\mathrm{L}$ genes were sequenced by outsourcing, analyzed by BLASTn and then manually edited and assembled to get partial sequences of $\mathrm{H}$ gene (1118bp) and L gene (268bp). The nucleotide sequences were submitted to DDBJ and the accession numbers obtained were LC011103.1 and KM868711.1 for $\mathrm{H}$ and $\mathrm{L}$ genes respectively.

Comparison of local isolate of CDV's partial $\mathrm{H}$ gene with that of the other $21 \mathrm{CDV}$ strains showed 91.9-95.9\% nucleotide and 92.995.5\% amino acid sequence identity. In case of partial L gene, there was 94.8-98.1\% nucleotide and 87.6-95.5\% amino acid sequence identity. Based on multiple sequence alignment, for both $\mathrm{H}$ and $\mathrm{L}$ amino acid sequences, LDH strain had the highest degree of identity with that of China and the lowest with that of the vaccine strains i.e. Ondersteport and Synder Hill. Percentage identity and divergence matrix for $\mathrm{H}$ and $\mathrm{L}$ gene of different CDV strains based on both nucleotide and amino acid alignment have been shown in (Fig 6). A total of five aa substitutions were found within the 372 aa in partial cds of $\mathrm{H}$ protein and four aa substitutions within the 89 aa in partial cds of $\mathrm{L}$ protein were observed.

The genotyping or phylogenetic analyses of CDV studied so far are mostly based on $\mathrm{H}$ protein, as it has the highest rates of mutation (Iwatsuki et al., 1997). Most of the vaccine strains (Lederle, Ondersteport, Convac and Synder Hill) are observed to cluster in America-1 type (Maria et al., 2014; Bi et al., 2015). In the present study, the phylogenetic tree based on the partial sequences of $\mathrm{H}$ and $\mathrm{L}$ genes showed a distinct clade for local CDV isolate which was clearly separated from the known vaccine group of CDVs (Fig. 7). The similar pattern has also been reported earlier based on partial $\mathrm{N}$ gene nucleotide sequences of two Indian CDV isolates (Pawar et al., 2011). Recently, another Indian CDV isolate was reported to make a separate branch compared to vaccine group of CDVs in phylogenetic tree not only based on $\mathrm{H}$ protein but also for $\mathrm{F}, \mathrm{M}$ and $\mathrm{P}$ proteins (Swati et al., 2015). An elaborative study is required for genotyping CDV from different places of India to focus on their evolutionary origin.

In conclusion, Growing CDV from clinical samples in mitogen stimulated dog lymphocytes was an effective and economical method to isolate wild-type CDV. Though the method requires a number of blind passages for appearance of proper $\mathrm{CPE}$, the presence of the viral RNA was easily detectable from the first passage. Molecular characterization of the partial $\mathrm{H}$ and $\mathrm{L}$ genes revealed that the isolated CDV was least identical to vaccine strains being used currently.

\section{Acknowledgements}

The authors are grateful to School of Animal Biotechnology, GADVASU for providing necessary research facilities. Special thanks to Dr. Jasdeep Singh for his help during sample collection and revision of the manuscript. Jawaharlal Nehru Memorial Fund is highly acknowledged for providing Jawaharlal Nehru Scholarship for Doctoral studies to Swati.

\section{References}

Altschul, S. F., Gish, W., Miller, W., Myers, E. W., Lipman, D. J. (1990): Basic local alignment search tool. J Mol Biol 215:403-410.

Appel, M. J. G. (1978): Reversion to virulence of attenuated canine distemper virus in 
vivo and in vitro. J Gen Virol 41:385393.

Appel, M. J. G., Jones, O. R. (1967): Use of alveolar macrophages for cultivation of canine distemper virus. Proc Soc for Exp Biol Med 126:571-574.

Appel, M. J. G., Pearce-Kelling, S., Summers, B. A. (1992): Dog lymphocyte cultures facilitate the isolation and growth of virulent canine distemper virus. J Vet Diag Invest 4:258-263.

Bi, Z., Wang, Y., Wang, X., Xia, X. (2015): Phylogenetic analysis of canine distemper virus in domestic dogs in Nanjing, China. Arch Virol 160:523527

Boyum, A. (1968): Isolation of mononuclear cells and granulocytes from human blood. Scand J Clinic Lab Invest 97:7789.

Ezeibe, M. C. O. (2005): Canine distemper in local dogs in Nsukka, Nigeria. Vet Rec 156:840-842.

Guo, L., Yang, S., Wang, C., Hou, R., Chen, S., Yang, X., Liu, J., Pan, H., Hao, Z., Zhang, M., Cao, S., Yan, Q. (2013): Phylogenetic analysis of the haemagglutinin gene of canine distemper virus strains detected from giant panda and raccoon dogs in China. Virol J 10:109.

Haig, D. A. (1956): Canine distemperimmunisation with avianised virus. J Vet Res 27:19-53.

Iwatsuki, K., Miyashita, N., Yoshida, E., Gemma, T., Shin, Y. S., Mori, T., Hirayama, N., Kai, C., Mikami, T. (1997): Molecular and phylogenetic analyses of the haemagglutinin $(\mathrm{H})$ proteins of field isolates of canine distemper virus from naturally infected dogs. J Gen Virol 78:373-380.

Kai, C., Ochikubo, F., Okita, M., Linuma, T., Mikami, T., Kobnne, F., Yamanouchi, K. (1993): Use of B95a cells for isolation of canine distemper virus from clinical cases. J Vet Med Sci 55:10671070.
Lan, N. T., Yamaguchi, R., Kawabata, A., Uchida, K., Kai, K., Sugano, S., Tateyama, S. (2006): Stability of canine distemper virus (CDV) after 20 passages in Vero-DST cells expressing the receptor protein for CDV. Vet Microbiol 118:177-188.

Lednicky, J. A., Meehan, T. P., Kinsel, M. J., Dubach, J., Bocchetta, M., Hungerford, L. L., Sarich, N. A., Witeki, K. E., Braid, M. D., Pedrak, C., Houde, C. M. (2004): Effective primary isolation of wild-type Canine distemper virus in MDCK, MV1 Lu and Vero cells without nucleotide sequence changes within the entire haemagglutinin protein gene and in subgenomic sections of the fusion and phosphoprotein genes. J Virol Methods 118:147-157.

Li, W., Li, T., Liu, Y., Gao, Y., Yang, S., Feng, N., Sun, H., Wang, S., Wang, L., Bu, Z., Xia, X. (2014): Genetic characterization of an isolate of canine distemper virus from a Tibetan Mastiff in China. Virus Genes 49:45-57.

Maria, A. E., Francisco, J. D., Julian, R. S. (2014): Phylogenetic evidence of a new canine distemper virus lineage among domestic dogs in Colombia, South America. Vet Microbiol 172:168-176.

Martella, V., Cirone, F., Elia, G., Lorusso, E., Decaro, N., Campolo, M., Desario, C., Lucente, M. S., Bellacio, A. L., Blixenkrone-Moller, M., Carmichael, L. E. (2006): Heterogeneity within the hemagglutinin genes of canine distemper virus (CDV) strains detected in Italy. Vet Microbiol 116:301-309.

Pawar, R. M., Raj, G. D., Gopinath, V. P., Ashok, A., Raj, A. (2011): Isolation and molecular characterization of canine distemper virus from India. Trop Anim Health Prod 43:1617-1622.

Sambrook, J., Russell, D. W. (2001): Molecular Cloning: A laboratory manual. 3rd ed. Coldspring Harbour Laboratory Press, New York, pp. 1.311.38 . 
Scagliarini, A., Battilani, M., Ciulli, S., Prosperi, S., Moranti, L. (2003): Molecular analysis of the NP gene of Italian CDV isolates. Vet Res Commun 27:355-357.

Seki, F., Ono, N., Yamaguchi, R., Yanagi, Y. (2003): Efficient isolation of wild strains of canine distemper virus in Vero cells expressing canine SLAM (CD150) and their adaptability to marmoset B95a cells. J Virol 77:99439950.

Sievers, F., Wilm, A., Dineen, D. G., Gibson, T. J., Karplus, K., Li, W., Lopez, R., McWilliam, H., Remmert, M., Soding, J., Thompson, J. D., Higgins, D. G. (2011): Fast, scalable generation of high-quality protein multiple sequence alignments using Clustal Omega. Mol Syst Biol 77:539.

Sultan, S., Lan, N., Ueda, T., Yamaguchi, R., Maeda, K., Kai, K. (2009): Propagation of Asian isolates of canine distemper virus (CDV) in hamster cell lines. Act Vet Scan 51:38.

Swati, Deka, D., Uppal, S. K., Verma, R. (2015): Isolation and phylogenetic characterization of Canine distemper virus from India. Virus Dis (published online) DOI 10.1007/s13337-015-0256$\mathrm{X}$

Tamura, K., Stecher, G., Peterson, D., Filipski, A., Kumar, S. (2013): MEGA6: Molecular Evolutionary Genetics
Analysis version 6.0. Mol Biol Evol 30:2725-2729.

Tan, B., Wen, Y. J., Wang, F.X., Zhang, S. Q., Wang, X. D., Hu, J. X., Shi, X. C., Yang, B. C., Chen, L. Z., Cheng, S. P., $\mathrm{Wu}$, H. (2011): Pathogenesis and phylogenetic analyses of canine distemper virus strain $\mathrm{ZJ7}$ isolate from domestic dogs in China. Virol J 8:520.

Tatsuo, H., Ono, N., Yanagi, Y. (2001): Morbilliviruses use signaling lymphocyte activation molecules (CD150) as cellular receptors. J Virol 75:5842-5850.

Thompson, J. D., Higgins, D. G., Gibson, T. J. (1994): CLUSTAL W: Improving the sensitivity of progressive multiple sequence alignments through sequence weighting, position specific gap penalties and weight matrix choice. Nucl Acids Res 22:4673-4680.

Zhao, J. J., Yan, X. J., Chai, X. L., Martella, V., Luo, G. L., Zhang, H. L., Gao, H., Liu, Y. X., Bai, X., Zhang, L., Chen, T., Xu, L., Zhao, C. F., Wang, F. X., Shao, X. Q., Wu, W., Cheng, S. P. (2010): Phylogenetic analysis of the haemagglutinin gene of canine distemper virus strains detected from breeding foxes, raccoon dogs and minks in China. Vet Microbiol 140:3442.

\section{How to cite this article:}

Swati, Dipak Deka and Ramneek. 2016. Detection of Local Isolates of Canine Distemper Virus by Reverse-Transcription Polymerase Chain Reaction. Int.J.Curr.Microbiol.App.Sci. 5(5): 757766. doi: http://dx.doi.org/10.20546/ijcmas.2016.505.077 